\title{
Historical Reconstruction, Reconstruction History, and the Proper Scope of Section 1981
}

\author{
Barry Sullivan†
}

On April 25, 1988, the United States Supreme Court, with four justices dissenting, entered an unusual order, restoring Patterson v. McLean Credit Union ${ }^{1}$ to the oral argument calendar and requesting supplemental briefs on the question "whether or not the interpretation of 42 U.S.C. $\S$ 1981 adopted . . . in Runyon v. McCrary" should be reconsidered."3 The parties in Patterson, like Congress ${ }^{4}$ and both courts below, had not questioned the general principle articulated in Runyon, that Section 1981'

\begin{abstract}
† Member of the Illinois and Massachusetts Bars. Partner, Jenner \& Block, Chicago, Illinois. The author would like to thank Neil H. Cogan, Harlon L. Dalton, Murray Dry, Stanley N. Katz, Jeffrey $T$. Shaw, and Winnifred F. Sullivan, all of whom provided useful comments on an earlier draft of this essay, and Brian Blanchard, whose research assistance was indispensable. Since this essay is a commentary, and not a work of original historical research, the author obviously is indebted to those whose original works are relied upon here. In addition, the author wishes to acknowledge his indebtedness to the excellent briefs filed in Patterson v. McLean Credit Union, 108 S. Ct. 1419 (1988).

1. 108 S. Ct. 1419 (1988). Barbara Patterson, a black woman, was employed for ten years as a teller and file coordinator by McLean Credit Union. Patterson v. McLean Credit Union, 805 F.2d 1143, 1144-45 (4th Cir. 1986). Following her discharge, she filed an action against her former employer under 42 U.S.C. $\$ 1981$ (1982), alleging that she had been harassed because of her race during her employment and subjected to racial discrimination, both in connection with promotions and at the time of her discharge. 805 F.2d at 1144. She also brought a pendent state law claim for intentional - infliction of emotional distress. Id. With respect to her racial harassment claim, Patterson alleged that McLean's president had told her at hiring that her co-workers would not like her because she was black, and that he subsequently made a practice of giving her too much work, singled her out for criticism at staff meetings, and required her to do sweeping and dusting, tasks not required of white tellers. Id. at 1145 . On one occasion, he told her that blacks were known to be slower than whites. Id. The district court directed a verdict for McLean, both on the Section 1981 harassment claim and on the pendent state claim; the jury returned a verdict for McLean on the Section 1981 promotion and discharge claims. Id. at 1144. After the Fourth Circuit affirmed, the Supreme Court granted certiorari to decide: (1) Whether a claim for racial harassment may be maintained under Section 1981, and (2) Whether the plaintiff in a Section 1981 promotion case must prove that she was better qualified than the person who received the promotion. $108 \mathrm{~S}$. Ct. 65 (1987). These questions were argued orally on February 29, 1988. Neither court below questioned Patterson's right to bring her promotion and discharge claims under Section 1981.
\end{abstract}

2. 427 U.S. 160 (1976) (Section 1981 not only prohibits official discrimination in making of contracts, but also reaches private conduct, such as activities of private school).

3. Patterson, $108 \mathrm{~S}$. Ct. at 1419.

4. See infra notes 26 and 32 and accompanying text (Congress frequently overrules court opinjons, but has not responded to Runyon with curative legislation).

5. 42 U.S.C. $\S 1981$ (1982) provides in relevant part:

All persons ... shall have the same right ... to make and enforce contracts, to sue, be parties, give evidence, and to the full and equal benefit of all laws and proceedings for the security of persons and property as is enjoyed by white citizens, and shall be subject to like 
prohibits racial discrimination by private parties. The Court acted entirely on its own motion in raising this question as to the continued validity of its own precedent. In doing so, the Court signalled its intention to look back, not only to 1968, when it held in Jones v. Alfred H. Mayer Co. ${ }^{6}$ that Section $1982^{7}$ reached private discrimination, ${ }^{8}$ or to 1976 , when it explicitly extended that holding in Runyon to cover Section 1981, but also to 1866 , when Congress first enacted these sections. ${ }^{\circ}$ Thus, the Court's order warrants revisiting the legal history of Reconstruction. ${ }^{10}$

\section{INTRODUCTION}

At the outset, it is well to remember that reconstructing the past is perilous work. As $\mathrm{H}$. Jefferson Powell has reminded us, most matters of historical interpretation necessarily involve probabilities, not certainties. ${ }^{11}$ The past can never be completely accessible to us, but we can judge historical assertions according to whether they are more probable than not, or more likely to be true than competing assertions. ${ }^{12}$ This principle applies not only to our assertions about the great questions of history, but also to the small corners in which lawyers and judges struggle with questions of legislative intent.

In some cases, legislative intent may be so clear as to obviate any need for discussion, let alone litigation. In many cases, however, Congress' intent is not obvious. Indeed, as two recent cases illustrate, congressional intent sometimes may be unclear even with respect to questions which, at least in retrospect, appear so basic as to cry out for answer. ${ }^{13}$ In Cannon

punishment, pains, penalties, taxes, licenses, and exactions of every kind, and to no other.

6. 392 U.S. 409 (1968) (Section 1982 prohibits racial discrimination by land developer in sale of property).

7. 42 U.S.C. $\S 1982$ (1982) grants to all citizens "the same right . . . as is enjoyed by white citizens . . . to inherit, purchase, lease, sell, hold, and convey real and personal property."

8. 392 U.S. at 442 .

9. Ch. 31, $\S 1,14$ Stat. 27 (1866) (reenacted by the Enforcement Act of 1870 , ch. 114, $\$ 18,16$ Stat. 140, 144 (1870)) (codified in Revised Statutes of 1874, $\$ \$ 1977-1978$ (1875), recodified at 42 U.S.C. $\$ \S 1981-1982$ (1982)). The Civil Rights Act of 1866 was enacted, over President Johnson's veto, in April 1866. Cong. Globe, 39th Cong., 1st Sess. 1857-61 (1866).

10. Reconstruction historiography has undergone a significant transformation in the past quarter century. E. Foner, Reconstruction xix-xxvii (1988); S. Kutler, Judicial Power and ReConSTRucrion Politics 1-6 (1968); Weisberger, The Dark and Bloody Ground of Reconstruction Histriography, 25 J.S. HisT. 427-47 (1959).

11. Powell, Rules for Originalists, 73 VA. L. REv. 659, 678-83 (1987).

12. Id.; see also I. Berlin, Historical. Inevitability 46-48 (1954); M. Bloch, The HistoRian's Craft 54-60 (Putnam trans. 1953); G. Himmelfarb, The New History and the Old 17 (1987).

13. See McCree, Bureaucratic Justice: An Early Warning, 129 U. PA. L. Rev. 777, 795 (1981). In some circumstances, of course, the problem may stem, not from the fact that Congress has failed to express its intent, but from the fact that Congress did not act with one intent, preferring, for political reasons, to leave some issues for resolution by the courts. See J. GRAY, The Nature and Sources OF THE LAw 172 (1921) ("But when a Legislature has had a real intention, one way or another, on a point, it is not once in a hundred times that any doubt arises as to what its intention was."). In the nineteenth century, however, courts were expected to resolve important public policy questions that we now consider more appropriate for legislative resolution. See infra note 122. 
v. University of Chicago, ${ }^{14}$ the Court confronted the question whether Congress intended to create a private right of action when it enacted Title IX of the Education Amendments of $1972 .{ }^{15}$ Likewise, in Merrill Lynch, Pierce, Fenner \& Smith v. Curran, ${ }^{16}$ the Court confronted the question whether Congress intended to recognize an implied right of action when it amended the Commodity Exchange $\mathrm{Act}^{17}$ by enacting the Commodity Futures Trading Commission Act of $1974{ }^{18}$ Despite the recent vintage of these enactments, and the voluminous legislative materials which the modern Congress typically creates in the course of legislating ${ }^{10}$ specific evidence of congressional intent was virtually non-existent. Thus, the Court was required to decide both cases by resort to highly technical canons of statutory construction. ${ }^{20}$

The Court's decisions in Cannon and Curran are noteworthy because they show that legislative history cannot always be deemed a font of certainty about legislative intent, even with respect to modern enactments. ${ }^{21}$ Moreover, a court faces even greater difficulties when it is required to divine legislative intent from older legislative materials. In that case, the language may no longer be fully understandable; $;^{22}$ the focus may be on

\footnotetext{
14. 441 U.S. 677 (1979).

15. 20 U.S.C. $\S 1681$ (1982).

16. 456 U.S. 353 (1982).

17. 7 U.S.C. $\S \S 1-26(1982)$

18. Pub. L. No. 93-463, 88 Stat. 1389 (1982).

19. See generally M. Malbin, Unelected Representatives: Congressional StafF and THE FUTURE OF REPRESENTATIVE GOVERNMENT (1980).

20. Curran, 456 U.S. at 394-95 (finding implied private right of action for customer against broker in fraud claim under Commodity Exchange Act); Cannon, 441 U.S. at 717 (finding implied private right of action under Title IX). Among other things, the Court observed in Cannon that it had "never refused to imply a cause of action where the language of the statute explicitiy conferred a right directly on a class of persons that included the plaintiff in the case." 441 U.S. at 690 n.13; see Sullivan v. Little Hunting Park, Inc., 396 U.S. 229 (1969); Jones v. Alfred H. Mayer Co., 392 U.S. 409 (1968).
}

21. We can take some comfort, however, from the fact that Congress apparently agreed with the holdings in both cases. See, e.g., Futures Trading Act of 1982, Pub. L. No. 97-444, 96 Stat. 2322-23 (confirming private right of action for commodities fraud).

22. See, e.g., St. Francis College v. Al-Khazraji, 107 S. Ct. 2022, 2026-28 (1987) (Court considers meaning of term "race" in nineteenth century, firding employment discrimination against individual because of Arab heritage actionable under Section 1981). In addition, our reading of legislative history must be guided by an understanding of contemporaneous legislative and judicial practice. For example, we now have a rather detailed system by which courts give differing amounts of weight to different types of legislative materials. See, e.g., Kelly v. Robinson, 107 S. Ct. 353, 362 n.13 (1986) (statement of non-members of legislature entitled to no weight); National Ass'n of Greeting Card Publishers v. U.S. Postal Serv., 462 U.S. 810, 832 n.28 (1983) (conference reports entitled to "great welght"); FEA v. Algonquin SNG, Inc., 426 U.S. 548, 564 (1976) (sponsors'statements entitled to "substanual weight"); NLRB v. Fruit \& Vegetable Packers Local 760, 377 U.S. 58, 66 (1964) (opponents' statements entitled to no. weight). In enacting legislation, Congress therefore acts in accordance with that system and attempts to compile a legislative record appropriate for judicial consideration.

In the nineteenth century, however, that system did not exist, and judicial recourse to legislative materials was not even thought to be an appropriate method of statutory construction. In one instance, Chief Justice Taney explained:

In expounding this law, the judgment of the court cannot, in any degree, be influenced by the construction placed upon it by individual members of Congress in the debate which took place on its passage, nor by the motives or reasons assigned by them for supporting or opposing amendments that were offered. The law as it passed is the will of the majority of both houses, 
once-burning issues that no longer even smolder (rather than on the narrow question that now commands attention); ${ }^{23}$ and the larger context in which the legislation was enacted may be inaccessible. ${ }^{24}$ These considerations suggest that the Court, having once completed the difficult and timeconsuming task of divining legislative intent, normally ought not plow the same ground again. ${ }^{25}$ Ordinarily, the Court should leave well enough alone, recognizing that Congress can always overrule the Court's erroneous reading of history. ${ }^{26}$ In Monroe $v . P a p e,{ }^{27}$ a case which required the

and the only mode in which that will is spoken is in the act itself; and we must gather their intention from the language there used, comparing it, when any ambiguity exists, with the laws upon the same subject, and looking, if necessary, to the public history of the times in which it was passed.

Aldridge v. Williams, 44 U.S. (3 How.) 9, 24 (1845); United States v. Trans-Missouri Freight Ass'n, 166 U.S. 290, 318-19 (1897) (same); United States v. Pacific R.R. Co., 91 U.S. 72, 79 (1875) (same); see Brest, The Misconceived Quest for the Original Understanding, 60 B.U.L. Rev. 204, 215-16 (1980); Congressional Debates: Can They Be Referred to in Construing Statutes?, 9 WAs̈. L. ReP. 242-43 (1881). At the very least, therefore, it seems clear that legislative intent cannot reliably be ascertained by applying modern rules of statutory construction to legislation that was enacted when those rules, being unknown, could have played no part in the legislative process. See Curran, 456 U.S. at 374 .

23. Cf. Wofford, The Blinding Light: The Uses of History in Constitutional Interpretation, $31 \mathrm{U}$. CHI. L. REv. 502, 533 (1964) ("History does not provide the answers to the problems of today; it merely helps to frame the questions").

24. See R. Lerner, The Thinking Revolutionary: Principle and Practice in the New REPUBLIC 31 (1987) ("[T]o put it more cautiously, it is a safer presumption to treat the past, including our national past, as different or as possibly even strange. In doing so we reduce the likelihood of our smoothing away or overlooking whatever might be distinctive in that earlier period. By preserving some sense of possible alienness, we leave ourselves open to being surprised and even to learning something."). It is noteworthy in this respect that the dissents in Jones and Runyon both looked to the Supreme Court's dictum in The Civil Rights Cases, 109 U.S. 3, 16-17 (1883), as an authoritative construction "almost contemporaneous[] with the passage of the [Civil Rights Act of 1866]. ..." Runyon, 427 U.S. at 192 (White, J., dissenting); Jones, 392 U.S. at 451 (Harlan, J., dissenting). However, no Reconstruction historian could possibly fail to perceive the great changes in society and public opinion that occurred between 1866 and 1883. See infra note 70 and accompanying text.

25. Constitutional construction requires a similar approach, but the enterprise is different in the sense that an erroneous constitutional interpretation can be cured only by the cumbersome process of constitutional amendment or by reconsideration by the Court itself. See, e.g., Monaghan, Stare Decisis and Constitutional Adjudication, 88 Colum. L. REv. 723 (1988); Stone, Precedent, the Amendment Process, and Evolution in Constitutional Doctrine, 11 HArv. J.L. \& PuB. PoL'y 67 (1988). In constitutional adjudication, therefore, the judiciary must be especially receptive to "the lessons of experience and the force of better reasoning." "Edelman v. Jordan, 415 U.S. 651, 671 n.14 (1974) (quoting Burnet v. Coronado Oil \& Gas, 285 U.S. 393, 407-08 (1931) (Brandeis, J., dissenting)).

26. In recent years, Congress frequently has overruled the Court on questions of statutory construction, particularly in matters of civil rights enforcement. See, e.g., Civil Rights Restoration Act of 1987, Pub. L. No. 100-259, 102 Stat. 28 (1988) (overruling Grove City College v. Bell, 465 U.S. 555 (1984)); Voting Rights Act Amendment of 1982, Pub. L. No. 97-205, 96 Stat. 131 (1982) (overruling City of Mobile v. Bolden, 446 U.S. 55 (1980)); Pregnancy Discrimination Act, Pub. L. No. 95-555, 92 Stat. 2076 (1978) (overruling General Elec. Co. v. Gilbert, 429 U.S. 125 (1976)). Indeed, Congress is so vigilant in this regard that it sometimes has overruled lower court decisions before the Supreme Court has had an opportunity to do so. See, e.g., United States v. Provenzano, 469 U.S. 14, 15 (1984) (new legislation renders moot case involving construction of Freedom of Information and Privacy Acts).

At the same time, it must be recognized that the Court imposes a substantial and costly burden on Congress when it requires the legislative branch to overrule a judicial decision, particularly where, as here, a whole body of case law would have to be codified to restore the law to its prior state. Thus, it is no answer to say that Congress is free to overrule Patterson if the Court chooses in Patterson to overrule Runyon.

27. 365 U.S. 167 (1961). 
Court to construe the phrase "under color of any statute" in Section $1983{ }^{28}$ Justice Harlan stated what must be deemed the litmus test in this area. Although he would have considered the question involved to be "very close indeed," 28 if presented as a matter of first impression, Justice Harlan was persuaded to join the majority based on the authority of Screws v. United States ${ }^{30}$ and United States v. Classic. ${ }^{31}$ Justice Harlan stated:

From my point of view, the policy of stare decisis, as it should be applied in matters of statutory construction, and, to a lesser extent, the indications of Congressional acceptance of this Court's earlier interpretation, require that it appear beyond doubt from the legislative history of the 1871 statute that Classic and Screws misapprehended the meaning of the controlling provision, before a departure from what was decided in those cases would be justified. Since I can find no such justifying indication in that legislative history, $I$ join the opinion of the Court. ${ }^{32}$

The principal aim of this essay is to show that history does not supply the quantum of proof required to warrant the overruling of Runyon. ${ }^{33}$ Indeed, far from showing that Runyon was wrongly decided, the historical materials provide ample support for the Court's holding that the Civil Rights Act of 1866 was intended to reach private, as well as official, discrimination. The Thirty-ninth Congress was little concerned with any theoretical distinction between public and private action in early 1866, but was committed to giving effect to the Thirteenth Amendment ${ }^{34}$ by

28. 42 U.S.C. § 1983 (1982).

29. 365 U.S. at 192 (Harlan, J., concurring).

30. 325 U.S. 91 (1945).

31. 313 U.S. 299 (1941).

32. 365 U.S. at 192 (footnote omitted). Although the main aim of this essay is to show that the Court's holding in Runyon is not demonstrably inconsistent with Congress' original intent, it is nonetheless true that "[t] there could hardly be a clearer indication of [present] congressional agreement with the view that $\$ 1981$ does reach private acts of racial discrimination." Runyon, 427 U.S. at 174-75 (emphasis in original). In numerous contexts, Congress has repeatedly indicated its understanding that Sections 1981 and 1982 reach purely private discrimination, and it has specifically tailored modern civil rights legislation to accord with that understanding. See 118 CoNG. REC. 3368-71 (1972); H.R. Rep. No. 238, 92d Cong., 2d Sess. 19 (1972); S. REP. No. 1011, 94th Cong., 2d Sess. 2, 4 (1976); H.R. ReP. No. 1558, 94th Cong., 2d Sess. 4 (1976).

33. In Jones, Justice Harlan undertook only the modest task of "endeavor[ing] to show that [the 1866] debates do not, as the Court would have it, overwhelmingly support the result reached by the Court, and in fact that a contrary conclusion may equally well be drawn." Jones, 392 U.S. at 454 (Harlan, J., dissenting) (emphasis added). Justice Harlan would have preferred to dismiss the writ as improvidently granted, because of the then-recent enactment of the Fair Housing Act, 42 U.S.C. $\S \S$ 3601 et seq. (1982). 392 U.S. at 450 . It seems unlikely, based on the principle Justice Harlan stated in Monroe, that he would have found the legislative materials sufficiently clear to warrant overturning Jones, Runyon, and their progeny.

34. The Thirteenth Amendment, which was ratified on December 6, 1865, provides:

Section 1. Neither slavery nor involuntary servitude, except as a punishment for crime whereof the party shall have been duly convicted, shall exist within the United States, or any place subject to their jurisdiction.

Section 2. Congress shall have the power to enforce this article by appropriate legislation. 
"secur[ing] to all persons within the United States practical freedom."35 The conclusion that Congress intended to reach private discrimination in the Civil Rights Act of 1866 may seem radical at first blush, ${ }^{36}$ but the purpose of the Thirteenth Amendment was itself radical, ${ }^{37}$ and, as one member of the Thirty-ninth Congress observed, the Civil Rights Act was

With respect to the reach of the Thirteenth Amendment, the Court has noted that "[t]here has never been any doubt of the power of Congress to impose liability on private persons under $\$ 2$ of ... [the Thirteenth] amendment, "for the amendment is not a mere prohibition of State laws establishing or upholding slavery, but an absolute declaration that slavery or involuntary servitude shall not exist in any part of the United States." Griffin v. Breckenridge, 403 U.S. 88, 105 (1971) (quoting The Civil Rights Cases, 109 U.S. 3, 20 (1883)). The Court also noted in Griffin that "the varieties of private conduct that [Congress] may make . . . civilly remediable extend far beyond the actual imposition of slavery or involuntary servitude." Id.

35. Cong. Globe, 39th Cong., 1st Sess. 474 (1866) (Sen. Trumbull); see The Civil Rights Cases, 109 U.S. at 22; Kaczorowski, Revolutionary Constitutionalism in the Era of the Civil War and Reconstruction, 61 N.Y.U. L. REv. 863, 895-99 (1986) (Thirteenth Amendment as positive law authority for congressional enforcement of citizens' rights).

36. Commentators have disagreed on whether Congress intended to reach private action under the Civil Rights Act. Some authorities who have directly addressed the question contend that Congress intended to reach purely private conduct. See, e.g., R. Kaczorowski, The Politics of Judicial InTerpretation: The Federal Courts, Department of Justice and Civil Rights, 18661876, at 112 (1985) (describing view of federal judges during Reconstruction that 1866 Act could be used to attack private discrimination); J. TEnBroek, The ANTISLavery Origins of the FourTEENTH AMENDMENT 162-64 (1951); Kaczorowski, To Begin the Nation Anew: Congress, Citizenship, and Civil Rights after the Civil War, 92 AM. Hrst. REv. 45 (1987); Kaczorowski, supra note 35; Kohl, The Civil Rights Act of 1866, Its Hour Come Round at Last: Jones v. Alfred H. Mayer Co., 55 VA. L. Rev. 272 (1969); Nieman, Andrew Johnson, the Freedmen's Bureau, and the Problem of Equal Rights, 1865-1866, 44 J.S. HIsT. 399 (1978); Note, Section 1981 and Private Discrimination: An Historical Justification for a Judicial Trend, 40 Geo. Wash. L. REv. 1024, 1025-33, 1036-39 (1972).

Other authorities have taken the opposite view. See, e.g., H. Belz, EMancipation and Equal Rights: Politics and Constitutionalism in the Civil War ERA 124 (1978); 6 C. Fairman, The Oliver Wendell Holmes Devise History of the Supreme Court of the United States, Reconstruction and Reunion: 1864-88, at 1213-60 (1971); D. Nieman, To Set the Law in Motion: The Freedman's Buread and the Legal Rights of Blacks, 1865-1868, at 112-13, 150 n.24 (1979); Bel2, The Civil War Amendments to the Constitution: The Relevance of Original Intent, 5 Const. CommentaRY 115, 129-33 (1988); Ervin, Jones v. Alfred H. Mayer Co.: Judicial Activism Run Riot, 22 VAND. L. REv. 485 (1969).

This essay suggests that the historical evidence clearly favors the Runyon holding, and that insufficient contrary evidence exists to warrant overruling a principle so firmly established as that enunciated in Runyon, its antecedents, and its progeny. See Goodman v. Lukens Steel Co., 107 S. Ct. 2617 (1987) (Section 1981 applicable to union in employee discrimination case); St. Francis College v. AlKhazraji, 107 S. Ct. 2022 (1987) (identifiable classes of persons subjected to intentional discrimination on basis of ancestry protected against private employment discrimination); General Bldg. Contractors Ass'n v. Pennsylvania, 458 U.S. 375 (1982) (intent to discriminate must be proven in Section 1981 case); McDonald v. Santa Fe Transp. Co., 427 U.S. 273 (1976) (Section 1981 prohibits discrimination against whites as well as blacks in private employment); Johnson v. Railway Express Agency, 421 U.S. 454 (1975) (follows Jones in dicta, holding that Title VII claim did not toll running of limitation period on Section 1981 claim); Tillman v. Wheaton-Haven Recreation Ass'n, Inc., 410 U.S. 431 (1973) (Sections 1981, 1982 prohibit community pool from withholding approval of assignment of membership because of race); Sullivan v. Little Hunting Park, Inc., 396 U.S. 229 (1969) (interpreting Section 1982 to prohibit community recreation association from withholding approval of assignment of membership because of race).

37. The question of slavery had exacerbated relations among the states since the framing of the Articles of Confederation. See Sullivan, Book Review Essay, 32 AM. J. Legal. Hrst. 173, 179 n.23 (1988). 
"absolutely revolutionary."38 In sum, the means which Congress adopted were commensurate with the evils it perceived.

\section{The General Background}

It is a commonplace that the Civil War transformed the Union, but it is difficult to appreciate fully the extent of that change or the velocity with which it occurred. It was indeed true, as George Templeton Strong confided to his diary in 1865 , that his generation had "lived a century of common life" since $1861 .^{38}$ In 1857 , only nine years before the enactment of the Civil Rights Act of 1866, the Supreme Court had declared that all persons of African descent belonged to a caste without any rights to citizenship, "the unhappy black race."40 Moreover, during the Secession Winter of 1860-61, Gongress seriously considered adopting an unamendable constitutional amendment which would have preserved slavery in the South and permitted its extension to the territories. ${ }^{41}$ As late as July 1861, a virtually unanimous Congress passed the Crittenden Resolution, affirming that the "established institutions" of the Southern states (including slavery) were not to be military targets. ${ }^{42}$ Throughout 1861 , military commanders closed their camps to fugitive slaves, and even returned them to their owners. ${ }^{43}$

In 1862, however, the Emancipation Proclamation profoundly and irreversibly altered the situation. ${ }^{44}$ The direct impetus for the Proclamation may have come from considerations of military necessity. ${ }^{45}$ Once issued, however, the Proclamation immediately altered the universe of post-war political options, and it soon became unthinkable that a peace secured by Northern victory could include a return to slavery. ${ }^{48}$ By December 1863,

38. Conc. Globe, 39th Cong., 1st Sess. 1291 (1866) (Sen. Morrill); see also id. at 1151-55 (Rep. Thayer) (calling Thirteenth Amendment "a revolutionary measure" and proposed act necessary "to carry to its legitimate and just result the great humane revolution to which I have referred"); Kaczorowski, supra note 36, at 54 ("evidence. . . supports the belief of framers that the Thirteenth and Fourteenth Amendments and the 1866 statute would bring about revolutionary changes in federal constitutionalism"); Kaczorowski, supra note 35, at 916 (opponents of Civil Rights Act feared "revolution worse than the Civil War").

39. 4 The Diary of George Templeton Strong 14 (A. Nevins and M. Thomas eds. 1952); see also D. Corbin, Argument in the Trial of the KKK before the United States Circuit Court, November Term 1871, Columbia, South Carolina 4 (1872) ("Gentlemen, we have lived over a century in the last ten years").

41). Dred Scou v. Sandford, 60 U.S. (19 How.) 393, 410 (1856) (citizen has property right in slaves, which extends into territory under protection of federal government).

41. H. Hyman, a More Perfect Union: The Impact of the Civil. War and ReconSTRUCrIION ON THE CONSTITUTION 40-46 (1973).

42. Id. at 172; E. FonER, supra note 10, at 4-5.

43. E. FONER, supra note 10, at 4-5.

44. 12 Stat. 1267 (1863) (slaves in Confederate states to be "forever free" as of January 1, 1863).

45. The order was based on Lincoln's powers as Commander in Chief and paved the way for the cnlistment of blacks in the Union army. See H. HyMAN \& W. Wiecek, EQUAL Justice UNDER LAw 253-55 (1982); H. JAFFA, EQUALITY AND LiberTy 140-68 (1965).

40. H. HYMAN, sufra note 41 , at 264 . 
as Lincoln noted, slavery had become a "moral impossibility."47 That view was confirmed by the election returns of 1864 , which brought to Congress a group of Republican leaders deeply committed to a genuine Reconstruction. ${ }^{48}$

The circumstances changed again, however, with Lincoln's assassination and Johnson's succession to the presidency. Beginning in May 1865, Johnson embarked on a policy of Presidential Reconstruction that proved "an unexpected tonic" to white Southerners. ${ }^{49}$ Almost immediately, "relief at the mildness of Johnson's terms for reunion mingled with defiant talk of state rights and resistance to black suffrage," as "[w]hite Southerners appreciated that Johnson's Reconstruction empowered them to shape the transition from slavery to freedom and define blacks' civil status without Northern interference." ${ }^{\prime \prime 0}$ As Southern whites regained social and governmental control under Johnson's Reconstruction policies, they severely restricted the Freedmen's access to the ordinary civil rights and liberties which white men enjoyed. ${ }^{\text {I1 }}$

By the time Congress met in December 1865, the Thirteenth Amendment had been ratified, but "it was apparent that policies which white Southerners thought showed a willingness to accept emancipation threatened in Republican eyes to make a mockery of Thirteenth Amendment liberty, if not actually to restore slavery." ${ }^{352}$ Under the leadership of Representative Thaddeus Stevens of Pennsylvania, the Joint Committee of Fifteen on Reconstruction was formed to monitor and react to conditions in the South, and to ensure that Johnson's narrowly conceived view of Northern victory did not carry the day. ${ }^{53}$ Among members of Congress, there was no groundswell of support for black suffrage in December $1865,{ }^{\text {s4 }}$ but there was increasing recognition that Johnson's policies did not go far enough. For Johnson, the Civil War had achieved only two things: the preservation of the Union and the formal destruction of slavery

47. $6 \mathrm{~J}$. Richardson, A Compilation of the Messages and Papers of the Presidents $189-91(1969)$.

48. H. HyMAN \& W. Wiecer, supra note 45, al 254-55 (by 1863, "Lincoln and most Americans had traveled great moral distances in a short time").

49. E. FONER, supra note 10 , at 189.

50. Id.

51. H. BELZ, supra note 36 , at 114 .

52. Id.

53. See generally The JouRnal of the JoInt Committee of Fifteen on ReConstruction (B. Kendrick ed. 1914) [hereinafter JourNal].

Professor Hyman has noted that the Civil War greatly altered the methods which Congress used to accomplish its legislative business. For example, floor debates decreased in importance as Congress came to rely increasingly on standing committees. H. HyMAN, supra note 41, at 182-83. "[T]he Civil War magnified the importance of joint committees generally. Some became standing committees of particular value for investigating legislation and watchdogging executive operations. These joint standing committees allowed concentration of information, expertness, and talent and avoided duplication of effort or energy." Id. at 183.

54. E. FONER, supra note 10 , at 245. 
as an institution. ${ }^{.5}$ Johnson could not appreciate that "[t]he restoration of the Southern States was not enough without a reconstruction of Southern minds." "ह6 Those whose vision went further, who recognized that the abolition of slavery had created an economic and social vacuum in the South, and who thus recognized the need for creating a new order, worked throughout the Reconstruction era to establish new constitutional standards, craft effective legislation, and deploy federal troops and agents to abolish all "badges and incidents" of slavery. By the end of 1865, mainstream Republicanism was increasingly aligned with the campaign for civil rights for the Freedmen. ${ }^{57}$

The Black Codes enacted by the Southern states under Presidential Reconstruction, as well as widespread acts of private discrimination and violence against the Freedmen, convinced Republican leaders that legislative action was needed. Those leaders recognized that the abolition of slavery, having destroyed the labor system that had existed for two centuries in the Southern states, necessarily called for the creation of a new labor system, for "the formation of new civil arrangements." 88 Indeed, most Northerners and black leaders saw the free labor contract as a key to practical freedom. ${ }^{\text {s9 }}$

Southern whites likewise conceived of the labor question as the driving issue of public policy. As one Southerner explained to South Carolina Governor Orr in December 1865, "you will find that this question of the control of labor underlies every other question of state interest." ${ }^{30}$ Former masters were neither prepared nor disposed to deal with former slaves on the grounds assumed by free labor ideology. They struggled to recreate the discipline and control of a slave system, while the Freedmen struggled - to discover freedom as independent workers. In a report released to Congress in December 1865, Major General Carl Schurz observed:

55. JOURNAL, supra note 53, at 152-53.

56. W. Brock, AN AMerican Crisis: Congress and Reconstruction, 1865-1867, at 14 (1963). Indeed, Johnson later became so obsessed with the correctness of his policies that, on one occasion during his "swing around the circle" in August 1866, "he intimated that Providence had removed Lincoln to elevate Johnson himself to the White House." E. FONER, supra note 10, at 265. Johnson's conduct, particularly his veto of the Civil Rights Act of 1866, alienated many members of Congress, and pushed Republicans with relatively safe seats into open warfare with him. See generally L. Cox \& J. Cox, Politics, Principle, And Prejudice, 1865-1866, at 202, 207 (1963); Kohl, supra note 36 , at $275-76$. When Congress eventually overrode Johnson's veto of the Civil Rights Act of 1866 , it was the first time that Congress had ever overridden a President on a major political issue.

57. L. Cox \& J. Cox, supra note 56, at 207.

During the war, a link had been forged between antislavery and the Union cause. Supporters of the Thirteenth Amendment had hoped that "with chattel bondage abolished and the Negro elevated to legal and civil equality, the pulsing heart of the system [of slavery] would be stilled and all appendages would soon atrophy and disappear." J. TENBROEK, supra note 36, at 149; see also H. HYMAN \& W. WIECEK, supra note 45 , at 297.

58. H. BeLz, supra note 36 , at 48 .

59. Id. at 58-64; E. FONER, supra note 10, at 242.

60. E. Foner, supra note 10, at 198 (quoting letter of William L. Trescot to Governor James L. Orr (Dec. 13, 1865)). 
The general government of the republic has, by proclaiming the emancipation of the slaves, commenced a great revolution in the south, but has, as yet, not completed it. Only the negative part of it is accomplished. The slaves are emancipated in point of form, but free labor has not yet been put in the place of slavery in point of fact[.] And now, in the midst of this critical period of transition, the power which originated the revolution is expected to turn over its whole future development to another power which from the beginning was hostile to it and has never yet entered into its spirit, leaving the class in whose favor it was made completely without power to protect itself and to take an influential part in that development. ${ }^{6 \mathbf{1}}$

Thus, a principal purpose of the Civil Rights Act of 1866 would be to grant to the Freedmen basic economic rights-to make and enforce contracts, to sue and be sued, and to purchase and lease property. These rights would enable them to act as autonomous, productive workers, who could hope to accumulate some material wealth. Congress' purpose was itself revolutionary because it would require a radical reordering of Southern society. ${ }^{62}$

Introducing the bill that would become the Civil Rights Act of 1866 , Senator Lyman Trumbull of Illinois stated that the legislation was needed to reinforce the Thirteenth Amendment: "When it comes to be understood in all parts of the United States that any person who shall deprive another of any right or subject him to any punishment in consequence of his color or race will expose himself to fine and imprisonment, I think such acts will soon cease." ${ }^{\prime 83}$ On the same day, and for related purposes, Trumbull introduced the bill that would be enacted, after some legislative modifications and two presidential vetoes, as the Second Freedmen's Bureau Act. ${ }^{64}$ The Act would extend the life of the Bureau and expand its authority to allow federal agenis to punish those who denied blacks the "civil rights belonging to white persons."

61. S. Exec. Doc. No. 2, 39th Cong., 1st Sess. 38 (1865)

62. It is not difficult to imagine the lack of enthusiasm with which former masters contemplated the need for dealing with the Freedmen over such matters as wages, when, only a few short years before, the masters had exercised total dominion over the Freedmen as property which had no legal rights whatever, even the right to marry. See T. CoBb, THE LAw OF SLAvery IN AMERICA 240 (1858); S. Elkins, Slavery 52-63 (2d ed. 1968); O. Howard, Autobiography of Oliver Otis Howard 279 (1907). Moreover, as Professor Foner has suggested, "[t]he ferment in the countryside, the history of other societies that had experienced emancipation, and ideologies and prejudices inherited from slavery, combined to convince the white South that only through some form of coerced labor could the production of plantation staples be resumed." E. FONER, supra note 10, at 198.

63. Cong. Globe, 39th Cong., 1st Sess. 475 (1866).

64. Id. at 129. The language of the two measures was quite similar. See id. at 314-18. See generally H. HYMAN, supra note 41 , at 449-59. Significantly, there is no evidence in the legislative history to support Justice Harlan's suggestion in Jones, that the Freedmen's Bureau bill was intended to be broader in scope because it included the word "prejudice" as well as "custom." 392 U.S. 409, 462 (1968) (Harlan, J., dissenting).

65. The Bureau of Freedmen, Refugees, and Abandoned Land was established in 1865, as part of the War Department, to provide relief assistance, legal protection, and land to the Freedmen and to white persons devastated by the war. See CoNG. Globe, 38th Cong., 2d Sess. 691 (1865). 
The constitutional amendments and statutes enacted in these years constituted a program to "win the peace" and were viewed as interrelated in the contemporary mind. ${ }^{86}$ They also reflected an emerging ideology of natural rights which, as Representative James F. Wilson observed when he introduced the Civil Rights bill in the House, "raise[d] by necessary implication the power in Congress to protect them." ${ }^{\prime 17}$ Indeed, it has been suggested that the postwar amendments and statutes, and the broadly conceived efforts of the Freedmen's Bureau, comprised "a sort of nineteenth century federal welfare" philosophy. ${ }^{88}$ When these enactments are viewed as a whole, it is impossible to argue that Congress objected, on doctrinal grounds, to the reaching of private action. ${ }^{69}$ The era of laissez-faire and much restricted civil rights opportunities was yet to come. ${ }^{70}$

\section{The Particular Background}

Conventional wisdom once held that the principal objective of the Civil Rights Act of 1866 was to nullify the infamous Black Codes that were enacted in several Southern states during 1865 and early 1866. The currency of that view has been debased, however, by historical research, which has shown that the Black Codes were quickly suppressed by the Freedmen's Bureau and the Union Army. In fact, by the time the Civil Rights Act was enacted in April 1866, the Codes were largely fair on

66. Zeigler, A Reassessment of the Younger Doctrine in Light of the Legislative History of Reconstruction, 1983 Duke L.J. 987, 992. In 1874, for example, Justice Bradley made the striking comment that the Fifteenth Amendment was "a constitutional extension of the Civil Rights Bill passed in 1866 ...." United States v. Cruikshank, 25 F. Cas. 707, 712 (C.C.D. La. 1874) (No. 14,897), affd, 92 U.S. 553 (1875).

67. Cong. Globe, 39th Cong., 1st Sess. 1118-19 (1866); cf. Kaczorowski, supra note 36, at 47-48 (congressional Republicans understood Thirteenth Amendment to guarantee "status and natural rights of citizens").

68. Kohl, supra note 36 , at 290 .

69. The absence of any such doctrinal objection is demonstrated with particular clarity in both the Enforcement Act of 1870 and the Ku Klux Klan Act of 1871 . Section 6 of the Enforcement Act stated:

[I] two or more persons shall band or conspire together, or go in disguise upon the public highway, or upon the premises of another, with intent to violate any provision of this act, or to injure, oppress, threaten, or intimidate any citizen with intent to prevent or hinder his free exercise and enjoyment of any right or privilege granted or secured to him by the Constitution or laws of the United States, or because of having exercised same, such persons shall be held guilty of felony. . . .

Ch. 114, $\S 8,16$ Stat. 140, 144 (1870). Section 2 of the Ku Klux Klan Act contained similar language, also prohibiting private conspiracies to "depriv[e] any person or any class of persons of the equal protection of the laws, or of equal privileges or immunities under the laws . . ."Ku Klux Klan Act of 1871, ch. 22, § 2, 17 Stat. 13 (current version at 42 U.S.C. $\$ 1985(3)$ (1982)). See generally Cogan, Section 1985(3)'s Restructuring of Equality: An Essay on Texts, History, Progress, and Cynicism, 39 Rutgers L. REv. 515 (1987).

70. Some would mark the line between the two eras with the Supreme Court's decision in The Civil Rights Cases, 109 U.S. 3 (1883). But see United States v. Louisiana, 225 F. Supp. 353, 369 (E.D. La 1963) (three-judge court) (Wisdom, J.) (by 1879, Louisiana was "firmly in the control of the White League"). aff d, 380 U.S. 145 (1965); C.V. WoOdWARD, REunion and REaction 204-15 (1951); Sullivan, The Honest Muse: Judge Wisdom and the Uses of History, 60 Tul. L. REv. $314,330-31$ (1985); inf; $a$ notes 116-19 and accompanying text. 
their face, ${ }^{71}$ and typically purported to grant to the Freedmen the technical, legal rights to buy, sell, own, and bequeath real and personal property; to make contracts; to travel freely; to give testimony on oath; and to invoke the jurisdiction of the courts. ${ }^{72}$ Nonetheless, it would be an overstatement to assert that Congress had no concern at all with the Black Codes (or the possibility that similar laws would be enacted in the future), and, indeed, such an assertion easily could be disproved by the legislative history of the Civil Rights Act. ${ }^{73}$

To be sure, the Black Codes exacerbated problems faced by the Freedmen. Equally, if not more troublesome, however, was the presence of pervasive and entrenched private discrimination. Rooted in the customs and mores of the white South, private discrimination relegated racial equality in civil rights to the status of "a mere abstraction recognized technically, but utterly inoperative to secure [for blacks] the exercise of the cardinal right of a freeman or citizen." " For example, even the right to sue for breach of contract would have little practical value if the Freedmen generally were unable to find a lawyer willing to represent them. ${ }^{75}$ In addition, the provisions of state law would be of little concern to the Freedman if the harm that he suffered was not even technically a violation of state law, as would be the case, for example, when a former master refused to contract with the Freedman at all, agreed to contract with him only on the most onerous terms, or acted in concert with other former masters to assure that the Freedman was unable to lease or buy land on any terms whatever. ${ }^{76}$

These scenarios play out again and again in the materials before Congress in late 1865 and early 1866, demonstrating that white Southerners were attempting to reintroduce as much as possible of the institution of

71. E. Foner, supra note 10, at 201; J. Sefton, The United States Army and ReconSTRUCTION, 1865-1877, at 70-72, 90 (1967).

72. H. Hyman \& W. WieceK, supra note 45, at 319. Although some Black Codes also included provisions prohibiting Freedmen from owning firearms, from living in certain areas, and from engaging in certain other activities, by and large, the language of the Black Codes was consonant with the language of the Civil Rights Act of 1866. See Kohl, supra note 36, at 277-78.

73. See, e.g., Jones, 392 U.S. 409, 455-73 (1968) (Harlan, J., dissenting) (discussing concerns with private action in legislative history of Civil Rights Act).

74. H. Hyman, supra note 41 , at 476 (quoting letter from General Oliver O. Howard to Secretary of War Edwin M. Stanton (Dec. 1, 1866)).

75. Even with a lawyer, the Freedman would have little chance of receiving justice at the hands of a state judge and jury. A British barrister commented that "the verdicts are always for the white man and against the colored man." H. LATHAM, BLACK AND WHITE 105 (1867), quoted in E. FoNER, supra note 10 , at 204 . General Schurz likewise reported that Southern whites, anxious to rid themselves of Freedmen's Bureau courts, assured their partisans that opening state courts to the Freedmen would have no practical effect, so long as all-white judges and juries determined "in each case . . whether the testimony of negro witnesses was worth anything or not." S. ExEc. Doc. No. 2, $39 \mathrm{th}$ Cong., 1st Sess. 34-35 (1865). "When Schurz objected that, loaded against blacks, state courts were most unlikely to punish a white abuser of a black employee for assault and battery, he was told: 'You must make some allowance for the prejudices of our people." "H. HYMAN, supra note 41, at 421. Thus, the problem was not limited to the facial unfairness of the law, but extended to the partiality of its administration.

76. See, e.g., H. HyMaN, supra note 41 , at 431 . 
slavery, not only through law, but also through custom and private practices. Thus, Congress well understood that far more than technical legal disabilities were at stake. ${ }^{77}$

As a practical matter, the commencement of debate on the Civil Rights Act of 1866 can be traced to December 1865, when Congress received the report of Major General Garl Schurz. ${ }^{78}$ Based on many discussions with Southern whites, Schurz found widespread commitment to the view that the Freedmen would not work without physical compulsion, an opinion which "naturally produced a desire to preserve slavery in its original form as much and as long as possible . . or to introduce into the new system that element of physical compulsion which would make the negro work."79 Schurz also described a pattern of private violence "by men who announce their determination to take the law into their own hands ... ." 80 This violence was not random, based on mere racial animosity, but frequently was aimed at preventing the Freedmen from exercising their new rights-c"calculated to produce the impression among those remaining with their masters that an attempt to escape from slavery would result in certain destruction." was the payment of paltry wages, the latter made possible by the absence of any true market for the Freedmen's labor. ${ }^{82}$ In addition, Schurz reported that many planters simply refused to pay wages they had agreed to pay to the Freedmen. ${ }^{83}$

77. In Jones, the Court rested its holding in part on Congress' recognition of widespread private discrimination against the Freedmen, and its intent to remove that discrimination. 392 U.S. at 427-30.

78. S. Exec. Doc. No. 2, 39th Cong., 1st Sess. (1865). Schurz had toured the South, at President Johnson's request, earlier in the year. He completed his report in November 1865, but Johnson did not approve its contents and refused to release it until the Senate adopted a resolution insisting that it be made public. Cong. Globe, 39th Cong., 1st Sess. 30, 78 (1865). When the report was finally released on December 19, Senator Sumner demanded that it be read aloud because it undermined Johnson's account of conditions in the South, id. at 79-80, but after a part of it was read, a motion was made and carried to require that the report be printed. Id. at 80 . On January 5,1866 , seventeen days after the release of the Schurz report, Senator Trumbull introduced the bill that was to become the Civil Rights Act of 1866. Id. at 129.

Justice Harlan suggested in Jones that the Schurz report has little importance because it was not mentioned very often in the debates. Jones, 392 U.S. at $462 \mathrm{n.28}$ (Harlan, J., dissenting). It is beyond dispute, however, that the Schurz report was the principal resource available to Senator Trumbull when he drafted the bill. It is also beyond dispute that the matters discussed in the report were frequently discussed (whether specifically referenced or not) during the debates. See infra note 130 and accompanying text. Thus, an equally (and probably more) plausible explanation is that the report was seldom mentioned because members of Congress were so familiar with it.

79. S. Exec. Doc. No. 2, 39th Cong., 1st Sess. at 17.

80. Id. at 18 (quoting report of Brigadier General Fessenden) (emphasis omitted).

81. Id. at 17.

82. Id. at 16, 19-20, 29-30. Schurz wrote:

[M]any attempts were made to ... adher[e], as to the treatment of laborers, as much as possible to the traditions of the old system, even where the relations between employers and laborers had been fixed by contract. The practice of corporal punishment was still continued to a great extent. ... The habit is so inveterate with a great many persons as to render, on the least provocation, the impulse to whip a negro almost irresistible.

Id. at 19-20.

83. Id. at 16,30 . 
Significantly, former masters generally did not refuse to contract with their former slaves, but recognized the use of labor contracts as a means of reintroducing practical slavery, insisting on terms so onerous as to leave the Freedmen worse off than they had been under slavery. ${ }^{84}$ In short, Schurz found that Southern whites, accustomed to their "peculiar" labor system, were not able to abide the free labor traditions of the North. Southern whites would be taken by "a paroxysm of fright," Schurz reported, if the Freedmen were to act "as free laborers in the North act every day without causing the least surprise."8s Without federal intervention, Schurz warned, the Freedmen would be subjected to "a system of coercion, the enforcement of which will be aided by the hostile feeling against the negro now prevailing among the whites, and by the general spirit of violence which in the south was fostered by the influence slavery exercised upon the popular character." ${ }^{\text {"88 }}$ Significantly, at the time Schurz prepared his report, he was not aware of any post-war laws which adversely affected the Freedmen, except for scattered ordinances in Louisiana and Mississippi, which he characterized as "mere isolated cases."

Also before the Thirty-ninth Congress was the report of General Oliver O. Howard, the head of the Freedmen's Bureau. ${ }^{88}$ Howard detailed the widespread use of corporal punishment and cruelty in employment, the formation of combinations for the purpose of extorting the Freedmen, the defrauding of the Freedmen of their wages, and the refusal of whites to fulfill their contracts with the Freedmen. ${ }^{89}$ Howard offered no particular criticism of state laws. To the contrary, he noted with approval that two Southern states had enacted laws permitting blacks to testify in their courts, ${ }^{90}$ and he warned of the "danger of the statute law being in advance of public sentiment." ${ }^{\prime \prime 1}$ Thus, like Schurz, Howard focused not on technical legal disabilities, but on practical discrimination effected through the actions of private parties.

Beginning on January 22, 1866, the Joint Committee on Reconstruction conducted hearings to examine the conditions prevailing in the South-

\footnotetext{
84. Schurz wrote:

[M]any ingenious heads set about to solve the problem, how to make free labor compulsory. . . . [Slome . . . planters tried to solve this problem by introducing into the contracts provisions leaving only a small share of the crops to the freedmen, subject to all sorts of constructive charges, and then binding them to work off the indebtedness they might incur. It being to a great extent in the power of the employer to keep the laborer in debt to him, the employer might thus obtain a permanent hold upon the person of the laborer.
}

Id. at $22,27,30$.

85. E. FoNER, supra note 10, at 122 (quoting from Carl Schurz's Letters from the South, 1951

GA. Hist. Q. 222, 239 (Mahaffey, ed.)).

86. S. Exec. Doc. No. 2, 39th Cong., 1st Sess. at 32.

87. Id. at 25 .

88. H.R. Exec. Doc. No. 11, 39th Cong., 1st Sess. (1866).

89. Id. at $26-30$.

90. Id. at 29 .

91. Id. at 33. 
ern states. ${ }^{92}$ Consistent with the Schurz and Howard reports, the bulk of the testimony adduced at these hearings concerned abuses by private parties, rather than discriminatory laws or discriminatory acts by public officials. In general, witnesses testified that the Freedmen were unable to make labor contracts on fair, non-discriminatory terms, or to buy, lease, or hold real and personal property, not because of legal disabilities, but because of private discrimination. For example, Major General A. H. Terry testified: "Many persons are treating the freedmen . . . with great harshness and injustice, and seek to obtain their services without just compensation, and to reduce them to a condition which will give to the former masters all the benefits of slavery. . .."93

Major General Edward Hatch, who had been stationed in Mississippi and Alabama after the close of the war, testified:

There are men in Mississippi who are willing to ... employ the negro and pay him a fair reward for his services. But a great portion of the people of Mississippi are not of large enough views. . . . They wish to control the negro and his labor in such a way that he will be compelled to remain with them for never less than a year, and upon their own terms. ${ }^{94}$

This theme was sounded throughout the hearings. ${ }^{85}$ It was reported, for example, that one planter had demanded that workers "sign a contract to work for him during their lifetime."'98 Other planters agreed to a standard

92. The Civil Rights Act, which was introduced on January 5, 1866, was referred to the Senate Judiciary Committee and reported out one week later, without any hearings. CoNG. GloBE, 39th Cong., Ist Sess. 211 (1866). The Joint Committee had been charged with investigating the conditions - prevailing in the South, id. at 24-30,47,57,60-62, 69, and it was that committee which commenced hearings on January 22. Transcripts of these hearings were available and mentioned during the debates on the Civil Rights Act, id. at 1267, and they were printed and widely disseminated prior to the vote on overriding President Johnson's veto. Id. at 1407-13. See REPORT OF THE JoINT CoMmITEE on Reconstruction, H.R. ReP. No. 30, 39th Cong., 1st Sess. (1866).

93. H.R. REP. No. 30, 39th Cong. 1st Sess., pt. ii, at 142.

94. JouRnal, supra note 53 , at 274-75.

95. If the Freedmen could be compelled in practice to work only for their former masters, or if planters could agree on standard terms and conditions of employment, there could be no free market for labor. Former masters generally were willing to go through the motions of "contracting" with the Freedmen for their labor, at low wages and subject to onerous conditions. The testimony also showed that planters were unwilling to pay to the Freedmen the same wages paid to white workers or even the amount that had been paid before the war for loaned slaves. H.R. REP. No. 30, 39th Cong., 1st Sess., pt. i, at 107-08; pt. ii, at 13, 30, 51-55, 175, 182, 210, 226-27, 234; pt. iii, at 6-12, 41-46, 103, $126,143,150$; pt. iv, at $37,46,69,88,116$. Because they balked at paying fair wages (with many refusing to pay any wages at all), there was no possibility that the Freedmen would be able to contract meaningfully to sell their labor. Journal, supra note 53, at 274-75 (Major Gen. Edward Hatch).

In addition, the testimony confirmed that violence frequently was used to compel the Freedmen to work for their former masters: "[F]reedmen [who] have gone from one county to another and made contracts. . . were brought back by men with their faces blackened, who whipped them and ordered them not to leave again . . . even when they were under no contract with their former masters." H.R. REP. No. 30, 39th Cong., ist Sess., pt. iii at 143; see also id. pt. iii at 8 (testimony concerning violence by private parties); pt. iv at 77,83 (same).

96. H.R. ReP. No. 30, 39th Cong. 1st Sess., pt. ii, at 228; see also id. pt. iv, at 116 ("The old 
form of contract designed to insure that the debts of a Freedman would equal or exceed his wages. ${ }^{97}$ In short, planters saw the labor contract as a means of perpetuating slavery under a different name.

Similarly, the testimony concerning the Freedmen's ability to purchase land also focused on problems involving private conduct. Except in Mississippi, the problem was not that the Freedmen were prohibited by law from purchasing or renting land, but that "[f]ormer slave owners [simply] will not lease or sell land to negroes." 98 In other words, the right to purchase or rent real estate was not technically withheld as a legal matter, but that right was worthless as a practical matter because white Southerners were not willing to deal with the Freedmen, and frequently agreed together not to do so. ${ }^{99}$

In sum, a substantial portion of the evidence before the Thirty-ninth Congress showed, as the Freedmen's Bureau explained, that "[s]lavery they have given up in the old form, but they want to subdue and keep in a low place the negroes, by some compulsion which it seems . . . they are trying to effect . . . privately . . . " 100 The Freedmen were to be free, "but free only to labor."101 As Professor Hyman has suggested, the members of the Thirty-ninth Congress were practical men who had little interest in "[s]ystematic constitutional theories as bases for comprehensive legislative schemes." ${ }^{\prime 102}$ But they were confronted with a serious practical problem: how to construct and implement a new labor system that was contrary to the deepest and most long-standing mores, customs, and practices of the South, the strength of which depended not simply, or even principally, on law, but on the most deeply held values of white society.

\section{The Text of the Statute}

The Civil Rights Act of $1866^{\mathbf{1 0 3}}$ was enacted to enforce the Thirteenth Amendment, which, in turn, was adopted to abolish slavery as a practical

master was not inclined to treat them differently from what he did when they were slaves. . . . The old planters were very unwilling to come down and make bargains in good faith").

97. Id. pt. i, at 107; pt. ii, at 270; pt. iii, at 7, 80, 124-25; pt. iv, at 9.

98. Id. pt. iii, at 122 .

99. Id. pt. ii, at $149,154,235-36,243$; pt. iii, at $6,25-27,30,36,45,62,66,71,101,151$; pt. iv, at $10,56,62,69,117$.

100. Id. pt. ii, at 243 .

101. E. FONER, supra note 10, at 134 (quoting Louisville Democrat newspaper).

102. H. HYMaN, supra note 41 , at 302 .

103. Section 1 of the Civil Rights Act of 1866,14 Stat. 27 (1866), conferred citizenship on nativeborn blacks and then provided that:

Such citizens of every race and color, without regard to any previous condition of slavery or involuntary servitude ... shall have the same right, in every State and Territory in the United States, to make and enforce contracts, to sue, be parties, and give evidence, to inherit, purchase, lease, sell, hold, and convey real and personal property, and to full and equal benefit of all laws and proceedings for the security of person and property, as is enjoyed by white citizens, and shall be subject to like punishment, pains, and penalties . . any law, statute, ordinance, regulation, or custom, to the contrary notwithstanding.

In Sections 2 and 3, Congress provided for criminal penalties and for the removal of suits to federal 
matter, and not simply to still the legal machinery of slavery. ${ }^{104}$ Section 1 of the Act broadly prohibited all discrimination in civil rights or immunities, based on "race and color, without regard to any previous condition of slavery or involuntary servitude," and proclaimed that all persons shall have certain equal civil rights, "any law, statute, ordinance, regulation, or custom to the contrary notwithstanding." ${ }^{\text {"10s }}$ At the outset, the logical geography of this language bears some discussion. The main thrust of Section 1, like that of the Thirteenth Amendment itself, is to define the Freedman's new status and rights. It is an "absolute declaration" of rights, rather than "a mere prohibition" of conduct. ${ }^{108}$

On the other hand, the enumeration of agencies prohibited from abridging those rights, which is contained in the final clause of Section 1, plainly reflects a secondary purpose. From a logical standpoint, Section 1 would invest the Freedman with the same rights even if the final clause had not been included. Thus, the final clause serves to emphasize, illustrate, and clarify the full scope of the rights created, by identifying agencies whose authority has been superseded by Congress' creation of these rights. In no sense, however, is the enumeration of those agencies essential to the creation of the rights themselves. The final clause proclaims that nothing, not even laws to the contrary, can prevail against the rights created in Section 1. Certainly, there is nothing in the structure of Section 1 to suggest that Congress intended to limit those rights by including the final clause. ${ }^{107}$

At all events, the language of the final clause, together with the sweeping language contained in the rest of Section 1, serves to underscore Congress' understanding that slavery was an economic institution, as well as a legal institution, and that it was rooted in the custom and private prac-

court. Id.; see S. KuTLER, supra note 10, at 148-49.

104. See, e.g., The Civil Rights Cases, 109 U.S. at 20; Strauder v. West Virginia, 100 U.S. 303, 308 (1880) (exclusion of blacks from jury service "is practically a brand upon them, affixed by the law; an assertion of their inferiority, and a stimulant to that race prejudice which is an impediment to securing to individuals of the race that equal justice which the law aims to secure to all others").

105. 14 Stat. 27 (1866).

106. The Civil Rights Cases, 109 U.S. at 20 (describing Thirteenth Amendment).

107. In this respect, it is necessary to consider Justice White's dissent in Runyon, in which he argued, based on a reviser's note, that Congress substantively amended Section 1 of The Civil Rights Act of 1866 by enacting the Revised Statutes of 1874. 427 U.S. 160, 195 n.6 (1976) (White, J., dissenting). However, the note upon which Justice White relied was written and published after the enactment of the Revised Statutes of 1874, see 18 Stat. 113 (1874), and thus has no bearing on congressional intent. Moreover, it is clear that Congress intended no substantive alteration of existing 'law when it enacted the Revised Statutes. After receiving the original commission's draft in 1872, Congress recognized that it would be "utterly impossible to carry the measure," if it altered existing law in any way, and therefore engaged a new reviser, Thomas Jefferson Durant, to ensure against any such change. See 2 CoNG. REc. H646-50 (daily ed. Jan. 24, 1874); 17 Stat. 579.

The need for avoiding any substantive change was reiterated by the sponsors. See, e.g., 2 Cong. REC. H647 (daily ed. Jan. 24, 1874) (Rep. Dawes) (expressing concern that existing statutes be changed in meaning and scepticism that revisions could be made without inadvertant change in meaning); id. at 647-48 (Ref) Poland); id. at 648-49 (Rep. Hoar). Moreover, Representative Lawrence specifically noted that there was no intention to alter the substance of Section 1 of the Civil Rights Act of 1866. 2 ConG. REC. ï827 (daily ed. Jan. 27, 1874). 
tices, as well as the law, of the Southern states. ${ }^{108}$ Viewed in this light, Congress' inclusion of the word "custom" in the Act is critically significant. As Robert Kohl has persuasively argued, the word "custom" can be read, logically and unambiguously, to mean "the 'custom' of white supremacy." 108 Whatever other connotations may be carried by the word "custom," the word certainly connotes private action, and its inclusion therefore reinforces Congress' intention to reach private conduct under the Act.

It makes little sense to suggest, as some commentators have done, ${ }^{110}$ that Congress intended in these circumstances to use the word "custom" only as a further reference to official action. First, that narrow reading appears inconsistent with the available evidence of contemporary usage, which shows that "custom" was used in the mid-nineteenth century to encompass purely private conduct. For example, during the Gold Rush in 1851 , the miners' private rules covering contract, property, and possession were adopted into California law with the following language: " $[P]$ roof shall be admitted of the customs, usages, or regulations established and in force at the bar, or diggings, embracing such claim; and such customs, usages, or regulations, when not in conflict with the constitution and laws of this State, shall govern the decision of the action." "custom" was used in precisely the same sense by Texas planter Frank B. Conner, who wrote to a family member in 1867 that planters should fix pay scales, and that anyone "breaking the established custom should be driven from the community." 112

Other examples could be given, but these should suffice to show that the essence of "custom" is private action. Indeed, it was Justice Harlan's candid recognition of that fact that required him to suggest in Jones that Congress may have intended to reach private discriminations, but only those "which were legitimated by a state or community sanction sufficiently powerful to deserve the name 'custom." "113 Justice Harlan's formulation, which narrows the definition of "custom" to encompass only those private actions which have the effective force of law, is not grounded in the legislative materials, ${ }^{114}$ but rather in Justice Harlan's intellectual

108. Professor Hyman has noted that "the black codes educated northern whites to facts long familiar to slaves, slaveowners, and abolitionists, teaching that slavery was never a simple relationship." H. Hyman, supra note 41, at 418 . "Over two centuries, numerous incidental customary and statutory constraints and disabilities had borne down on the slave in order that the master's property rights and social control remain unimpaired." Id.

109. Kohl, supra note 36, at 289.

110. See, e.g., 6 C. FAIRMAN, supra note 36, at 1238-44; see also Jones, 392 U.S. at 471-73 (Harlan, J., dissenting).

111. Civil Practice Act of California of 1851, $\S 621$, quoted in J. GRAY, supra note 13, at 296-97.

112. E. Foner, supra note 10, at 139 (quoting Letter from Frank B. Conner to Lemuel P. Conner (Sept. 26, 1866)).

113. Jones, 392 U.S. at 457 (Harlan, J., dissenting).

114. In support of his theory, Justice Harlan pointed only to the fact that Congress used the 
need to reconcile Congress' clear intention to reach some private action with his general "state action" approach to the statute. ${ }^{115}$ However, this preoccupation with the modern dichotomy between the public and the private spheres, which has become central to Fourteenth Amendment analysis, has never been applied to the Thirteenth Amendment, under which the Givil Rights Act was enacted. Indeed, the doctrinal importance of this dichotomy was not manifest in $1866,{ }^{118}$ and probably did not become clear until 1883, when the Supreme Court decided The Civil Rights Cases. ${ }^{117}$ Thus, it is not surprising that the congressional debates do not belabor the point. ${ }^{118}$ Indeed, even to ask, in these circumstances, whether Congress

additional word "prejudice" in the Freedmen's Bureau bill. Id. As previously noted, however, there is no discussion in the legislative history to show that Congress intended any significance to be attached to this slight verbal variation. See supra note 64 .

115. That crabbed definition of custom is inconsistent with evidence of nineteenth-century usage. See supra notes 111-12 and accompanying text. It is also inconsistent with modern usage. When we speak of custom, we mean conduct which is approved or tolerated in varying degrees by various segments of society, not simply conduct which is so well or universally endorsed as to constitute law in all but name. Illegal practices, such as bid-rigging or bribery, may be sufficiently acceptable to (or at least tolerated by) certain segments of society as to constitute customs at various times or places, but they cannot, by definition, have the force of law. Moreover, a custom is a dynamic social phenomenon which necessarily carries varying degrees of authority during its natural life cycle. See, e.g., A. Milne, Human Rights and Human Diversity: An Essay in the Philosophy of Human Righrs 113 (1986).

116. Legislators like Senator Trumbull looked at the world in a less complicated way when they asserted, quite simply, that the purpose of the Act was to "break down all discrimination between black men and white men." CoNG. Globe, 39th Cong., 1st Sess. 599 (1866). Ignoring the import of such statements, the state action theorists nonetheless pronounce the Section 1 legislative materials as insufficient to show that Congress affirmatively intended to take the truly exceptional (to them) step of reaching private action. They then buttress their argument with the assertion that Congress was too mindful of states' rights and laissez-faire principles to have targeted private discrimination.

Laissez-faire was directly invoked, however, only by President Johnson in his veto message. $6 \mathrm{~J}$. RichaRDSON, supra note 47, at 406-13 (vetoing bill because it interferes with "relations between - inhabitants"). Moreover, the Freedmen's Bureau already was deeply involved in many of the same private liability matters that would pass to the federal courts under the Civil Rights Act. Bureau officials attempted to offer redress to Freedmen who had been robbed, assaulted, or denied wages by whites. In addition, Bureau officials (sometimes to the disadvantage of the Freedmen) had been substantially involved in the formation and enforcement of individual labor contracts. E. FONER, supro note 10, at 149

117. 109 U.S. at 20 (Fourteenth Amendment prohibits only governmental interference with constitutional rights). The Civil Rights Cases effectively ended Reconstruction by validating the Compromise of 1877. See C.V. Woodward, supra note 70, at 245; Brest, State Action and Liberal Theory: A Casenute on Flagg Brothers v. Brooks, 130 U. PA. L. REv. 1296, 1300-01 (1982); Goodman, Professor Brest on State Action and Liberal Theory, and a Postscript to Professor Stone, 130 U. PA. L. REv. 1331, 1332-34 (1982). The complicated relationship between the Thirteenth and Fourteenth Amendments is a subject that lies beyond the scope of this essay. Nonetheless, it is worth noting that Professor tenBroek concluded, based on his study of the legislative materials relating to the Fourteenth Amendment, that "the protection intended [under the Fourteenth Amendment] was not merely against state action." J. TENBROEk, supra note 36, at 186; see also H. HYMAN, supra note 41, at 439 ("Almost no one anticipated, when formulating the Fourteenth Amendment in 1866 or when ratifying the Fifteenth in 1870, that the rights specified in both postwar amendments would be interpreted to affect only the public acts of the small number of the state officials rather than private actions.").

118. In his dissent in Jones, Justice Harlan noted that Congress had spent a great deal of time debating the imposition of federal obligations upon state officials, and that little time was devoted to the applicability of the statute to purely private action. Jones, 392 U.S. at 475 (Harlan, J., dissenting). From this fact, Justice Harlan essentially concluded that Congress' silence on the "more difficult" case of private discrimination indicated its lack of intent to reach it. In 1866, however, it was the imposition of federal obligations upon state officials, not the proscription of private discrimination, 
intended to reach private as well as official discrimination may be a category mistake. ${ }^{119}$

Finally, Congress' inclusion of the word "custom" in the text of the Act is particularly significant because courts in the nineteenth century construed statutes by looking to the statutory language and the general history of the times, rather than to specific fragments of the legislative debates. ${ }^{120}$ Indeed, Senator Sherman insisted during the debates that the meaning of the Act was plain on its face, that it defined:

the incidents of freedom, and [assured] that these men must be protected in certain rights, and so careful is it in its language that it goes on and defines those rights, the right to sue and be sued, to plead and be impleaded, to acquire and hold property, and other universal incidents of freedom. ${ }^{121}$

To limit enforcement of the Act to cases in which the denial of freedom was accomplished by state action not only would have made those "incidents of freedom" far from universal, but would have rendered the word "custom" mere surplusage. Thus, we should presume that Congress included the word "custom," knowing what it meant in common usage, and intending that it would be given that meaning by the courts. ${ }^{122}$ In other

that would have seemed the more difficult case. See In re Kentucky v. Dennison, 65 U.S. (24 How.) 66 (1861); Prigg v. Pennsylvania, 41 U.S. (16 Pet.) 539 (1842); Kaczorowski, supra note 36, at 62-63. In addition, of course, Congress was very concerned about the imposition of federal criminal liability, a novel occurrence in the nineteenth century, when the federal criminal code was virtually non-existent, and criminal law was thought to be the responsibility of the states. See infra note 138 .

119. See G. Ryle, The Concept of Mind 16-17 (1949). To frame the question in that way is to indulge in a category mistake because it focuses the issue in a way quite foreign to the framers, who, unlike us, were not required to view the issue through the lens of modern Fourteenth Amendment analysis. When that category mistake is properly understood, there is little force to the suggestion that the legislative materials are insufficient to show that Congress affirmatively intended to take the truly exceptional step of reaching private action. Viewed in its own light, rather than ours, the step is far less exceptional.

120. See supra note 22 and accompanying text. As Holmes put it: "We do not inquire what the legislature meant, we ask only what the statute means." Holmes, The Theory of Legal Interpretation, 12 Harv. L. Rev. 417, 419 (1898-99). See also United States v. Hartwell, 73 U.S. (6 Wall.) 385, 396 (1868) ("If the language be clear it is conclusive. There can be no construction where there is nothing to construe.").

121. Cong. Globe, 39th Cong., 1st Sess. 744 (1866).

122. The narrow reading also sounds hollow in light of the way in which the heart of the problem was explained to Congress, both in the Schurz and Howard reports and in the hearings before the Joint Committee. See supra notes 78-91 and accompanying text. As Robert Kohl has noted, "[t]he Joint Committee found many instances where private individuals refused to sell or lease land to Negroes, not because they feared any 'community sanctions' but because such sales would establish a 'precedent,' or because of such private scruples as 'repugnance,' adverse 'feeling,' 'instinct,' or 'sentiment." "Kohl, supra note 36, at 289.

Clearly, the "conservative" aspect of this legislation was that it was aimed at securing only "civil rights," and not "political rights" (such as suffrage) or "social rights." But Congress intended, with respect to civil rights, that the Freedmen should have the "same right . . . as is enjoyed by white persons. . . ." 42 U.S.C. $\$ 1981$ (1982). Congress' aim was to secure practical equality, not the kind of formalistic equality described by one of Anatole France's characters in Le Lys Rouge, prohibiting rich and poor alike from sleeping under bridges, A. France, The Six Greatest Novels of ANATOLE FRANCE 837 (W. Stephens trans. 1909), and there is no evidence in the legislative history 
words, it seems likely that the Supreme Court, had it been required to construe Section 1981 at the time it was first enacted, would not have gone beyond the text itself to conclude that it reached private action.

\section{The Congressional Debates of 1866}

The course of the 1866 debates has been recounted at length in the Court's prior opinions. ${ }^{123}$ This section will not rehearse the legislative history in full, but will confine itself to examining several key points, which will place in context the fragments that have been invoked by one side or the other.

First, the need for legislation to deal with subversion of the Freedmen's rights, whether by private or official forces, was a theme sounded throughout the debates. Indeed, even before he introduced the bill, Senator Trumbull stated that it was intended to deal with the danger that "by local legislation or a prevailing public sentiment in some of the States persons of the African race should continue to be oppressed. . .."124 Later, Trumbull observed that the bill was not intended to punish "[s]tate officers, especially, but everybody who violates the law."125 In this respect, it is also telling that Trumbull earlier had opposed a bill proposed by Senator Henry Wilson of Massachusetts, ${ }^{126}$ which would have prohibited only discriminatory laws, because Wilson's bill did not go far enough. ${ }^{127}$ The aim of Trumbull's bill was to "secure[] freedom in fact." ${ }^{\text {"128 }}$ Likewise, Representative James Wilson of Iowa argued that "[l]aws barbaric and treatment inhuman are the rewards meted out by our white enemies to our colored friends. We should put a stop to this at once and forever." 128 These statements were not mere rhetorical flourishes; they evinced an un-

to suggest that Congress feared intruding upon private economic relationships. Admittedly, the line to be drawn between "social" and "economic" relationships may not always be obvious, but that seems to have been a detail that Congress left for the courts. See H. HyMaN, supra note 41, at 227 ("Far better for Congress to let judges bear ultimate responsibility"); see also M. BAXTER, DANIEL WEBSTER \& The Supreme Court 35 (1966); S. Kutler, supra note 10, at 126; G. White, The AMrerican Judicial TRADITION 178-99 (1976); Bickel, The Original Understanding and the Segregation Decision, 69 HaRv. L. Rev. 1, 59-65 (1955); Levinson, New Perspectives on the Reconstruction Court, 26 STAN. L. REv. 461, 483 (1974).

Moreover, there is no question as to Congress' intention to create a private right of action when it enacted Section 1. In the nineteenth century, it was commonly recognized that "in every case, where a statute enacts, or prohibits a thing for the benefit of a person, he shall have a remedy upon the same statute for the thing enacted for his advantage. . . " Couch v. Steel, 3 El. \& B1. 402, 411, 118 Eng. Rep. 1193, 1196 (Q.B. 1854). Accord Merrill Lynch, Pierce, Fenner \& Smith v. Curran, 456 U.S. 353, 374-76 (1982); Marbury v. Madison, 5 U.S. (1 Cranch) 137, 163 (1803). Thus, it is necessary to read Section 1 as a free-standing provision.

123. See, e.g., Memphis v. Green, 451 U.S. 100, 131-36 (1981) (White, J., concurring); Jones, 393 U.S. at $422-37$.

124. Cong. Globe, 39th Cong., 1st Sess. 77 (1865) (emphasis added).

125. Id. at $500(1866)$.

126. S. 9, 39th Cong., 1st Sess. (1865); Cong. Grobe, 39th Cong., 1st Sess. 2, 39 (1865).

127. Cong. Globe, 30 th Cong., 1st Sess. 43 (1865).

128. Id. at 476 (1866).

129. Id. at 1118 (emphasis added). 
derstanding of the need to reach the evil itself, not simply its official manifestation.

Second, Congress widely discussed the information received from the Schurz and Howard reports, and from the hearings of the Joint Committee, ${ }^{130}$ all of which showed that the problem to be remedied was more subtle than de jure discrimination. ${ }^{131}$ For example, Senator Sumner reported that former slave owners in South Carolina had agreed in public meetings not to rent lands to the Freedmen or "to contract with any freedman unless he can produce a certificate of regular discharge from his former owner. ${ }^{\prime 132}$ It is against the background of such reports that we must read statements such as Trumbull's, that "[i]t is idle to say that a man is free who cannot go and come at pleasure, who cannot buy and sell, who cannot enforce his rights . . . which the first clause of the [Thirteenth] Amendment meant to secure to all."133 What was at issue, as Senator Sumner put it, was the relegation of the Freedmen to "a condition of practical slavery." 134

Third, the fact that a large part of the actual debate was concerned with discriminatory state action is subject to misinterpretation. For example, it is beyond dispute that Congress was genuinely concerned with the Black Codes that were being enacted by "the controlling class in the insurgent States," as Representative James Wilson referred to the governments established under Presidential Reconstruction. ${ }^{135}$ In addition, it is certainly true that Congress was genuinely concerned about issues of fed-

130. See, e.g., id. at 39-40 (Sen. Wilson) (Freedmen worse off in most respects than they were as slaves); id. at 93-95 (Sen. Sumner) (concerted activities by planters to prevent free labor market and refusal of planters to pay wages); id. at 1159-60 (Rep. Windom) (purpose of bill is "to secure to a poor, weak class of laborers the right to make contracts for their labor, the power to enforce the payment of their wages, and the means of holding and enjoying the proceeds of their toil"); id. at 1833-35 (Rep. Lawrence) (quoting extensively from accounts of private violence and discrimination against blacks); id. at 1838-39 (Rep. Clarke) ("Every mail brings to us the records of injustice and outrage"); id. at 1267 (Rep. Raymond), 1839 (Rep. Clarke) (citing Joint Committee testimony and Schurz report).

131. Laws are enacted by societies to enforce values that might not otherwise be espoused. See, e.g., E. SHILs, TRadition 189 (1981) ("Legislation was a great invention for the changing of society in accordance with procedural rules and within the framework of the written or unwritten constitution. Legislation is intended to institute changes which will change tradition but which become traditions once they have been made."); see also $1 \mathrm{~J}$. STORY, CoMmeNTaries on THE Constitution of THE UNITED STATES $§ 134$ (1833) (discussing "the dangers of legislation [enacted upon mere theory,] without consulting the habits, manners, feelings, and opinions of the people"). If values can be enforced without positive law, because of the strength of custom or the degree of social approbation given to certain conduct, there may be no need for law, and the distinction between public and private action lacks real consequence. In addition, certain conduct, which is neither prohibited nor required by law, may be widely approved or tolerated by certain segments of society, so that certain values may be promoted, wholly outside the realm of positive law, and, indeed, without the need for any concerted social action or enforcement. In those circumstances as well, the distinction between public and private action may be meaningless.

132. Cong. Globe, 39th Cong., Ist Sess. 93 (1865).

133. Id. at 43 .

134. Id. at 127; see also supra notes 69-70,116-19 and accompanying text (discussing absence of congressional emphasis on distinction between public and private spheres).

135. Cong. Globe, 39th Cong., 1st Sess. 1118 (1866). 
eralism. ${ }^{136}$ But to focus narrowly on these references to state laws, as some commentators have done, ${ }^{137}$ misses the fact that the real issue was whether the federal government should be involved in local criminal justice matters. The debates indicate that some members of Congress had serious concerns that the Act signalled an expansion of federal criminal jurisdiction. These concerns stemmed not from a reluctance to commit the federal government to the protection of civil rights, but from an appreciation of the extremely limited role which the federal government had taken in criminal law since the founding of the Republic. ${ }^{138}$ Thus, for example, Representative John A. Bingham of Ohio expressed concern that the bill represented "the terrors of the penal code within organized States."139

Congress' concern about sailing these uncharted seas is not surprising. Nor is it surprising that these areas received substantial attention during the debates. It would be a mistake, however, to infer from the forensic prominence of these subjects that Congress was uninterested in private discrimination, or that it did not intend to reach private discrimination under the Act. In this respect, it is important to recognize that the agenda for the debates largely was set by the opponents of the bill, who focused on two issues: the nullification of state laws and the imposition of federal criminal penalties on state officials. ${ }^{140} \mathrm{By}$ and large, the proponents of the Act directed their fire at answering those arguments.

Some opponents of the Act did recognize its broad sweep, and specifically objected that it would reach purely private conduct. ${ }^{141}$ For example, Senator Garett Davis of Kentucky, in a frequently cited passage, observed that the purpose of the Act was to strike down "discriminations ... against the negro race" in most of the states "made by their constitutions

136. Kaczorowski, supra note 36, at 60.

137. See, e.g., 6 C. Fairman, supra note 36, at 1214 (quoting Cong. Globe, 39th Cong., 1st Sess. 476 (1866) (Sen. Trumbuli) (Act would "have no operation in any State where the laws are equal, where all persons have the same civil rights without regard to color or race.")). It is noteworthy that Fairman's writings give little weight to recent historical research and analysis.

138. In 1812, the Supreme Court held that there was no federal common law of crimes cognizable in the federal courts. United States v. Hudson, 11 U.S. (7 Cranch) 32, 33-34 (1812); accord United States v. Coolidge, 14 U.S. (1 Wheat.) 415 (1816); see Jay, Origins of Federal Common Law: Part Two, 133 U. PA. L. Rev. 1231, 1292, 1299 (1985). In addition, there was little federal criminal statutory law. See G. Mueller, Crime, LAw AND THE Scholars 32-33 (1969) (there was no "orderly system of federal criminal laws" until 1897); D. Flanigan, The Criminal Law of Slavery and Freedom: $1800-1868$, at 364 (May 1973) (Ph.D. dissertation available through University Microfilms, Ann Arbor, Michigan) (southern justices of the peace sat at apex of in:ensely local systems of criminal justice). If anything, Congress simply underestimated the actual amount of federal activity that would be required to accomplish its goals. Thus, Senator Trumbull predicted that fining and imprisoning "one or two in a State, and the most prominent ones I should hope at that," would "break up this whole business." ConG. Globe, 39th Cong., 1st Sess. 475 (1866).

139. Cong. Globe, 39th Cong., 1st Sess. at 1292.

140. See, e.g., id. at 1120-23 (Rep. Rogers) ("Has Congress the power to enter the domain of a State, and destroy its police regulations with regard to the punishment inflicted upon negroes?').

141. Id. at 1268 (Rep. Kerr); id. at 1416 (Sen. Davis). In addition, President Johnson made the point in his veto message. $6 \mathrm{~J}$. Richardson, supra note 47 , at $412-13$ (criticizing bill for interfering with relations between "inhabitants"). 
and statutes. . . "142 But when Davis, a Democrat, proceeded to list examples of discrimination that would violate the Act, he included: providing "softly cushioned pews" for whites in churches, assigning to whites the best cabins on steamships, and segregating travellers by race "on railroads, national, local and street."143 Although these specific examples may well have exceeded the intentions of the bill's supporters, those proponents did not contradict Davis's assertion that the $A$ ct would reach privale action. In sum, Democrats objected to the bill on the ground that it would work a revolution in American law, ${ }^{\mathbf{1 1 4}}$ but that, as Senator Morrill observed, was precisely what was required in the midst of a revolution. ${ }^{145}$

\section{CONCIIUSION}

The Thirty-ninth Congress was committed to securing "practical freedom" for the Freedmen. The historical materials show that Congress' attention was not focused entirely on the official acts of truculent Southern judges, legislators, and other public officials. Nor was Congress concerned only with statutes that discriminated in explicit terms against the Freedmen. On the contrary, Congress was well aware of the role played by private discrimination in the South's recalcitrant refusal to accept the necessary consequences of the Civil War, and it intended to provide a remedy for such discrimination. Furthermore, since it was acting pursuant to the Thirteenth Amendment, Congress was not doctrinally obligated to parse the public and private qualities of the obstacles which white Southerners were bent on interposing in the path of Congress' legislative goals.

$\Lambda s$ in most matters of historical interpretation, there is room for debate. If due regard is to be paid to the historical materials, however, and if precedents are to be overruled only on the clearest evidence that the Court previously has misperceived the intent of Congress, there is no proper ground for overruling Runyon. The historical evidence docs not show that the Court erred "bcyond doubt"146 when it held in Runyon that the Thirty-ninth Congress intended to reach private discrimination under the Givil Rights Act of 1866.

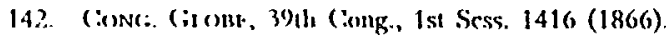

143. Id. 11 180\%, App. 18185 .

141 Id. at 598 (Sen. D.wis) ("Ilere the honorable Senator ["Trumbull] in one short hill breaks down all line domestic systems of law that prevail in all the states, . . . and he bresks down all the penal laws that inflet punishment or penaliy upon all the prople of the States exeept so far as those laws shall be uniform in their application.").

145. Id. at 1291. When introducing the bill in the House, Representative Janes Wilson observed that "the praclice of the States leaves us no avenue of escape, and we must do our duty by supplyung lie protection which the States deny." Id. al 1118; spe alse id. at 77 (Sen. "Trumbull) (under the

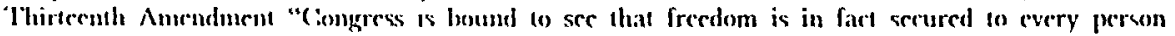
thromphout the l.ond").

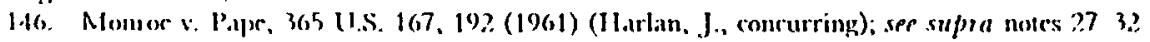
.t1d decomp.onying text (explaining significante of IJarlan's reasoning) 